\title{
US Conservative and Libertarian Experts and Solar Geoengineering: An Assessment
}

Jean-Daniel Collomb

\section{(2) OpenEdition \\ Journals}

Electronic version

URL: https://journals.openedition.org/ejas/14717

DOI: 10.4000/ejas. 14717

ISSN: 1991-9336

Publisher

European Association for American Studies

\section{Electronic reference}

Jean-Daniel Collomb, "US Conservative and Libertarian Experts and Solar Geoengineering: An Assessment", European journal of American studies [Online], 14-2 I 2019, Online since 18 November 2021, connection on 18 November 2021. URL: http://journals.openedition.org/ejas/14717 ; DOI: https://doi.org/10.4000/ejas. 14717

This text was automatically generated on 18 November 2021.

Creative Commons License 


\title{
US Conservative and Libertarian Experts and Solar Geoengineering: An Assessment
}

\author{
Jean-Daniel Collomb
}

1 As the international community and the United States have been struggling with how to address human-made climate change, some voices have started calling for conscious efforts to engineer the earth's climate in order to limit the amount of damage humankind will incur in the $21^{\text {st }}$ century and beyond. Consider, for instance, former Exxon Mobil CEO and US Secretary of State Rex Tillerson's remark to the effect that climate change is "an engineering problem and it has engineering solutions."

2 According to J.G. Shepherd, "geoengineering is deliberate intervention in the climate system to counteract man-made global warming." ${ }^{2} \mathrm{He}$ goes on to reference two main classes of geoengineering, "direct carbon dioxide removal and solar radiation management that aims to cool the planet by reflecting more sunlight back to space." So far, much of the discussion regarding geoengineering has been taking place in the Northern Hemisphere, especially in English-speaking countries, although it has also been happening on occasions in China. ${ }^{4}$

Over the last few years, the growing visibility of geoengineering has prompted some to accuse conservative and libertarian climate skeptics of being hellbent on using the promise of geoengineering to downplay the need for strong mitigation policies such as a carbon tax or a cap-and-trade system. Chief among those critics of free-market conservatives is Australian philosopher Clive Hamilton. In a book entirely devoted to geoengineering, Hamilton lambasts it as "a Promethean urge" ${ }^{5}$ and bemoans the fact that technology is systematically called upon to resolve problems begotten by technological development, while also underlining the potentially disastrous sideeffects of geoengineering. In a passage specifically devoted to US free-market think tanks, he highlights the paradox of the climate skeptics who favor unprecedented techno-fixes to solve a problem the existence or seriousness of which they doubt, ${ }^{6}$ which leads Hamilton to characterize geoengineering as "an essentially conservative 
technology." More broadly, the main idea behind the critique of geoengineering is that the Earth-system is simply too vast, too complex, and too unpredictable for humanity to engage in such large-scale experiments. ${ }^{8}$

4 Even before the publication of Hamilton's book, the journalist Eli Kintisch had cast very serious doubts about the motives of conservative and libertarian policy experts who have shown interest in solar geoengineering:

By focusing the conversation about climate change on geoengineering, conservatives have a new way to recast the climate problem that takes carbon dioxide completely out of the picture. Keeping the Pinatubo option as a worst-case scenario in their back pocket allows them to appear to act responsibly while avoiding its cause: the greenhouse effect, which humanity has exacerbated by burning fossil fuels. ${ }^{9}$

5 Recently Hamilton's and Kintisch's concern about a potential convergence between free-market conservative climate skeptics and proponents of climate engineering has been echoed several times. ${ }^{10}$

6 As if to prove Hamilton and Kintisch right, former House Speaker Newt Gingrich had confidently asserted in a 2008 online article published in Human Events that "geoengineering holds forth the promise of addressing global warming concerns for just a few billion dollars a year." 11 However, other conservative backers of geoengineering appear to be a lot less sanguine about its political prospects, even in conservative and Republican circles. For instance, Lee Lane and J. Eric Bickel, two of the most vocal supporters of solar geoengineering in US free-market think tanks, complain that geoengineering is a political orphan on both sides of the political spectrum:

In effect, for different reasons, the two politically mobilized ends of the political spectrum on climate change tend to reject use of SRM. The Greens do so because they regard it as morally abhorrent. Conservatives do so because, in rationalizing their opposition to GHG control, they have come to insist that man-made climate change is a hoax. The practical effect is that no organized support exists for research into SRM. ${ }^{12}$

7 Nevertheless, an emblematic quote one way or another does not suffice to generalize about what conservative and libertarian experts think and say about climate engineering. I will therefore try to map out the various positions put forward by policy experts in major conservative and libertarian think tanks regarding geoengineering. More specifically, I have chosen to focus on solar geoengineering, often referred to as SRM (Solar Radiation Management), for two reasons.

8 First, SRM is the category of climate engineering that is most often discussed because it is viewed as more promising than carbon capture. According to its proponents, the deployment of SRM could be quick, could produce more immediate and significant effects than carbon capture, and may prove relatively cheap, at least compared with the costs of mitigation or carbon capture. Second, it seems to me that lumping together SRM and carbon capture, which both fall into the broader category of geoengineering, might turn out to be confusing for the reader. In fact, there are highly significant differences between SRM technologies and carbon removal technologies. For example, SRM would do nothing to reduce GHG concentrations in the atmosphere. Nor could it ameliorate ocean acidification. By contrast, carbon removal, if successful and conducted on a large enough scale, could help humankind make progress on these two fronts. I will therefore focus on SRM. 
9 I have decided to focus on US conservative and libertarian think tanks for two reasons. First geoengineering is mainly discussed in elite circles as very few people are even aware of its existence. An even more limited fraction of the public seem to be familiar with its complexities and intricacies..$^{13}$ The very low visibility of SRM means that it is taken into consideration almost exclusively by public policy experts and academics, especially economists and philosophers. Paul Burstein has shown that topics that do not elicit significant interest from the general public, as appears to be the case for SRM, give special interests more leeway to shape policy outcomes..$^{14}$ As a result, at least for the time being, it makes sense to concentrate on what is said and written in freemarket think tanks.

10 Second, the positions staked out by those think tanks should give us pause because they can potentially influence the decision-making process when the Republican party controls part or all of the federal government. For instance, President Trump's deregulatory push and his hostility toward the idea of a social cost of carbon are both rooted in the policy prescriptions made by think tanks like the Competitive Enterprise Institute, the Cato Institute, and the Heritage Foundation. ${ }^{15}$

11 US think tanks began to emerge during the Progressive Era. Their goal was to give a voice to experts and specialists in public discourse, which is why their members did their utmost to stay clear of political squabbling and partisan confrontations. ${ }^{16}$ This began to change from the 1960s onwards when an increasing number of think tanks turned more militant and began to sound more ideological. This trend was especially notable among conservative and libertarian think tanks, many of which aspired to lay out a consistent ideological doctrine. ${ }^{17}$ Jason Stahl claims that those think tanks sought to call into question the so-called liberal consensus and undermine what they perceived as the ideological hegemony of the Left in US politics and among policy-makers. ${ }^{18}$ In the process, Stahl argues, they succeeded in promoting the notion of a marketplace of ideas so that each ideological side would get equal access to the public debate regardless of the factual validity of their claims. ${ }^{19}$ No doubt the blatantly ideological nature of the advocacy of those think tanks has markedly undermined their credibility. But their publications offer a detailed and sophisticated reflection of the ideology that undergirds Republican policies in the $21^{\text {st }}$ century. That is why it seems crucial to gain a clear understanding of where the experts who staff free-market think tanks stand on SRM, how diverse or monolithic their positions are, and how prominently SRM features in their reflections and recommendations.

12 Hence I will provide an analysis, both quantitative and qualitative, of the contents put online by the following think tanks: the American Enterprise Institute, the Cato Institute, the Competitive Enterprise Institute, the Heritage Foundation, the Hoover Institution, the Manhattan Institute, the Reason Foundation, the Heartland Institute, the Niskanen Center, and R-Street. The first seven are listed in James G. McGann's Global Go to Think Tank Index Report. They have been chosen because they feature among McGann's list of the 90 most influential think tanks in the United States. ${ }^{20}$ Heartland belongs in this study because, for decades, it has been one of the most vocal freemarket think tanks on the issue of climate change and has been identified as one of the fountainheads of climate skepticism in the US..$^{21}$ The Niskanen Center and R-Street were founded very recently, in 2014 and 2012 respectively. I have elected to include them in my study on account of their staff's pronounced interest in climate and energy issues. R-Street's case is also worth studying as it was set up by former Heartland experts who 
had grown uncomfortable with the institute's militant and hard-hitting climate skepticism.

13 In order to analyze the perspectives of those think tanks and their experts on SRM, I have opted for an interdisciplinary approach as I rely on a quantitative method in line with the standards of political science while also resorting to textual analysis in order to study the substance of the positions taken by free-market experts from the perspective of the history of ideas. I have looked at the book chapters, articles, press releases, policy briefs and blog posts they have published on the issue of solar geoengineering until the end of 2018. I will first endeavor to define SRM and sketch out the terms of the public and academic discussion about it in the US. Then I will provide a quantitative assessment of the state of the debate in the world of US conservative and libertarian think tanks with a view to measuring how prominent this policy proposal is and gauging the extent of conservative and libertarian experts' support for or hostility toward SRM. Lastly, I will present a qualitative analysis of the arguments laid out for and against solar geoengineering by those experts.

\section{Solar geoengineering in America}

14 Solar radiation management refers to a family of emerging technologies, the purpose of which is to reflect sunlight back into space so as to limit temperature increases temporarily. Two caveats have to be borne in mind with regards to SRM: solar geoengineering does not help lower GHG concentrations in the atmosphere, which cause climate change, and it has no impact on ocean acidification, which stems from soaring carbon emissions. If successful, what SRM could do is allow humankind to slow down the rise in temperatures and use the delay to actually decarbonize the world economy while also building more resilient infrastructures. SRM encompasses several techniques, including marine cloud brightening, cirrus cloud thinning, urban whitewashing, and the use of orbital mirrors to reflect sunlight back into space. ${ }^{22}$ Stratospheric sulfate aerosols are far and away the SRM technique that is most frequently mentioned and discussed because it is touted by its proponents as the cheapest and quickest way of slowing warming. Put simply, it consists in mimicking the cooling effect of volcanoes by spraying sulfur into the stratosphere, twenty kilometers above the surface of the Earth. ${ }^{23}$

15 The term geoengineering was coined by Cesare Marchetti in 1977, but various forms of it had been previously considered by the Soviet and US military establishments during the cold war. ${ }^{24}$ Yet, in the context of the fight against human-made climate change, SRM was seldom discussed until the late 1990s. Things slowly began to change in the early 2000s. For example, geoengineering was designated by national security experts Peter Schwartz and Doug Randall as one among a series of policy instruments to address human-made climate change. ${ }^{25}$ The genuine turning point for the visibility of SRM occurred in 2006 when the Dutch geo-chemist and Nobel-Prize winner Paul Crutzen, who wields considerable influence in environmentalist circles thanks to his decisive contribution to the effort to reverse ozone depletion, published an article in support of research into SRM. Crutzen's move was spurred by political inertia in the face of climate change and his impression that mitigation policies, which he continued to wholeheartedly support, would fall short of what was necessary to avert catastrophic climate change. Under such circumstances, Crutzen claimed, research into the 
potential and feasibility of SRM was worth pursuing so that future generations might have a contingency plan to grapple with the worst effects of climate change.

The publication of this article was a highly consequential and controversial move because of the enormous prestige Crutzen enjoys in scientific and environmentalist circles. In effect a scientific figure of authority was lending legitimacy to an emerging technology which many environmental advocates wanted to keep out of the climate change conversation lest it be used as an opportunity to downplay the need for vigorous mitigation policies. Unsurprisingly, Crutzen experienced a severe backlash from several of his colleagues, ${ }^{26}$ some of whom even tried to talk him out of publishing his article. ${ }^{27}$ And indeed, once the article was published the importance of geoengineering in policy discussions about climate change began to grow. More and more articles, books, and reports were being published in order to discuss the merits of SRM. Chief among those publications was a special report of the British Royal Society in 2008. SRM also featured in the 2014 Summary for Policy-Makers of the IPCC.

It bears repeating that SRM technologies are emerging technologies, which means that what is at stake is whether significant funding will be invested in research into them. Recently several scientific institutions have cautiously recommended that funds be allocated to research into climate engineering. In 2015, for instance, the Committee on Geoengineering Climate of the US National Academies of Sciences underscored, albeit with many caveats, "the need for more research on albedo modification." ${ }^{28}$ Three years later the American Geophysical Union published a statement urging "national funding agencies to create substantial research programs on climate intervention so that the risks and opportunities are much better understood." ${ }^{29}$ In both cases SRM is presented as a potential complement to a set of strong mitigation and adaptation policies. It should be noted, however, that the 2018 IPCC Report for Policy-Makers does not include SRM in its portfolio of measures to address climate change, citing, among other concerns, "substantial risks and institutional and social constraints to deployment related to governance, ethics, and impacts on sustainable development." 30

I now turn to a brief presentation of the terms of the debate about SRM in the United States. Stefan Schäfer and Sean Low have argued that the public discussion about geoengineering, unlike that about recombinant DNA in the 1970s, does not just revolve around technical issues but has also resulted in "an inclusive narrative that also focuses on complex social, political, and ethical issues." ${ }^{31}$ As a matter of fact, many social scientists, be they economists, philosophers, or historians of science, have already contributed to this discussion.

19 Ken Caldeira and David Keith, who are two of the most prominent and visible champions of SRM research in North America, are careful to preface their advocacy of SRM by an unequivocal word of support for vigorous mitigation policies. SRM, they insist, is not a substitute for emissions reduction but a contingency plan..$^{32}$ Many of the proponents of research on SRM also claim that it would not dispense humanity from significantly reducing GHG emissions as diligently as possible. ${ }^{33}$ Far from presenting SRM as an unproblematic and ideal solution to climate change, Caldeira and Keith claim that our inability to enact strong enough mitigation measures should prompt us to consider a plan B in the form of SRM, which, they write, is "shockingly inexpensive" and "can be deployed rapidly." ${ }^{34}$ Hence their call for immediate funding for research.

20 Central to SRM advocacy is the desperation argument, which is predicated on the fear that rich countries will not change sufficiently, at least not quickly enough, so that 
humankind needs to invest in research to be ready to deploy SRM technologies if and when it becomes necessary. ${ }^{35}$ On a more optimistic note, Oliver Morton, who also believes that we will not be able to decarbonize the world economy quickly enough, claims that geoengineering could allow us to buy time so as to continue to grow the world economy and improve the living standards of the inhabitants of developing countries ${ }^{36}$ an argument echoed by David Keith. ${ }^{37}$ The objective would be to limit the impact of climate change while generalizing the benefits of material prosperity, which, Morton asserts, will not happen without "a massive expansion of the energy systems of developing countries." ${ }^{38}$

This approach to SRM seems to align perfectly with the worldview of the so-called ecomodernists, who hope to mobilize the resources of science and technology to overcome environmental and energy challenges while upholding and broadening very high standards of economic development. ${ }^{39}$ That is why, for example, Steward Brand has come out in support of geoengineering. ${ }^{40}$ In his much-discussed book Enlightenment Now, Steven Pinker, who unequivocally sides with the eco-modernists, briefly touches on SRM. After summarizing all the risks involved, Pinker cautiously endorses support for research into SRM techniques. ${ }^{41}$ Likewise, the utilitarian philosopher Peter Singer has offered tentative support for SRM research, which, he thinks, could be useful as a plan B on the condition that effective global governance mechanisms be put in place so as to make unilateral and irresponsible uses of geoengineering less likely. ${ }^{42}$

Unsurprisingly SRM has also aroused doubts, fears, and a lot of skepticism. ${ }^{43}$ First and foremost critics of SRM are usually quick to point out that trying to control the global climate is a fool's errand because of the sheer complexity of the Earth-system. For instance, the geophysicist James Lovelock has cast doubts on our ability to keep "the Earth in homeostasis" for a very long time, claiming that efforts to engineer the global climate would probably create more problems than it would solve. ${ }^{44}$ This concern is echoed by Hulme who underlines the many uncertainties involved in solar geoengineering. 45

The fear of the potential effects of geoengineering on climate politics is also a recurrent theme among SRM skeptics. Although he reluctantly supports research, Stephen Schneider worries that the promise of geoengineering might reinforce political apathy and complacency. ${ }^{46}$ According to the logic of this argument, the implementation of mechanisms like carbon taxes or cap-and-trade systems would then become even more difficult to achieve than now. Yet, according to Kahan et al, exposure to information about climate engineering may not actually make the general public more complacent about the dangers of climate change. ${ }^{47}$ They even contend that awareness of the existence of SRM could in fact reduce cultural polarization over climate science somewhat by making some segments of the public that are reluctant to engage with climate science more likely to do so because geoengineering better aligns with their worldview than taxing carbon.

Other critics of SRM argue that resorting to geoengineering would be unfair to future generations. Wil Burns points out that implementing SRM schemes would force future generations to hold on to them for an indefinite period of time lest temperatures rise abruptly. ${ }^{48}$ In contrast to David Keith who has suggested that SRM experiments could be gradually and safely phased out, ${ }^{49} \mathrm{Jack}$ Stilgoe worries that that solar geoengineering "will initiate a perpetual experiment with the planet." ${ }^{50}$ 

the American Enterprise Institute and the Cornwall Alliance, affirmed that conservatives were unlikely to look favorably on geoengineering because of the emphasis they usually put on the limitations of human understanding. ${ }^{55}$ On closer examination, however, several conservative free-market advocates appear to be considering SRM seriously. It is, therefore, worth assessing the importance of geoengineering in the deliberations of conservative and libertarian experts regarding climate change. More specifically, I will try to answer three sets of questions. First, I intend to determine how prominent SRM is in their analyses and policy prescriptions: how often is it discussed? Is it central or marginal in their thinking about climate change? Second, I will study the timing of their statements: are there periods and circumstances when SRM is more prominent, and others when it becomes less visible? Third, it seems crucial to map out the diversity of perspectives on SRM among conservative and libertarian experts: when they do broach this subject, do they tend to be favorable or unfavorable to it? Or do some of them adopt a neutral and noncommittal approach to it?

Finally, concerns about geopolitical risks usually loom large in the critiques leveled at SRM. As a matter of fact, even David Keith concedes that the geopolitical risks are the warned against "parochial geoengineering, where the current generation secures shortterm benefits for itself only by passing on much more serious long-term risks to the future, and predatory geoengineering, where one country chooses a particular form of geoengineering mainly to disadvantage its geopolitical rivals." ${ }^{52}$ Stephen Schneider also believes that the implementation of SRM schemes could be rife with conflict and create situations that would be all the more volatile as "institutions currently do not exist with the firm authority to assess or enforce responsible use of the global commons." ${ }^{53}$ Joshua Horton counters that SRM is very unlikely to be deployed unilaterally because, absent multilateral cooperation, geoengineering efforts would almost certainly defeat their purposes simply because the effects of one unilateral SRM scheme could be cancelled, or at least derailed, by another SRM scheme..$^{54}$ Hence the strong incentive for consensus and cooperation between nations.

certainly continue to evolve quickly. Over the last twenty years several conservative and libertarian experts have set out to participate to this debate. I will now turn to their contributions to it.

\section{A quantitative assessment of the state of the debate in the world of conservative and libertarian think tanks}

In order to get a sense of the importance and visibility of SRM in the analyses and prescriptions of conservative and libertarian experts, I have examined the material that free-market think tanks put on their websites. These websites contain substantial archives going back decades and featuring a vast range of documents, such as policy briefs, press releases, book chapters, blog articles and congressional testimonies. They 
are used by those think tanks to advertise their positions and their experts' policy recommendations.

What is most striking is how little the ten think tanks under study have said about SRM so far, even though they have published a wealth of documents about climate and energy issues for several decades.

\begin{tabular}{|c|c|c|}
\hline & $\begin{array}{l}\text { Number of publications in } \\
\text { which solar geoengineering } \\
\text { is mentioned }\end{array}$ & $\begin{array}{l}\text { Number of publications } \\
\text { about climate change } \\
\text { (mentions of solar } \\
\text { geoengineering included) }\end{array}$ \\
\hline$A E I$ & 35 & 1,230 \\
\hline Cato Institute & 8 & 1,832 \\
\hline CEI & 8 & 9,050 \\
\hline Heartland & 16 & 6,149 \\
\hline Heritage Foundation & 1 & 12,959 \\
\hline Hoover Institution & 10 & 841 \\
\hline Manhattan Institute & 6 & 416 \\
\hline Niskanen Center & 4 & 98 \\
\hline Reason Foundation & 7 & 441 \\
\hline$R$-Street & 5 & 530 \\
\hline Total & 100 & 33,546 \\
\hline
\end{tabular}

Table 1: share of solar geoengineering in the online publications of major US conservative and libertarian think tanks between 1996 and November 2018

In other words, SRM appears extremely marginal in the larger framework of their positions regarding climate change. After eliminating occurrences that were not directly relevant to it, I have found that by the end of 2018, SRM had been mentioned only six times on the website of the Manhattan Institute even as this website contained 416 references to climate change. The Competitive Enterprise Institute's website features 8 mentions of SRM out of 9,050 references to climate change. The most spectacular example is that of Heritage with only one quick mention out of 12,959 references to climate change. The only partial outlier is the American Enterprise Institute with 35 occurrences. Nevertheless SRM still accounts for a tiny fraction of AEI's 1,230 publications on climate change.

It is then useful to find out when those references occurred, which might reveal the impact of particular political, economic or scientific developments on their positions. Hence I have decided to reference how the 100 relevant references to SRM on the websites of the ten think tanks under study are distributed in six time periods: before 1997, the year of the Kyoto protocol; from 1997 to the beginning of George W. Bush's presidency in 2001; from 2001 to 2006, when Paul Crutzen published his muchdiscussed and highly controversial endorsement of public funding for SRM research; from 2006 to the beginning of the Obama presidency in 2009; from early 2009 to early 
2017, which spans the presidency of Barack Obama; from early 2017 to the end of 2018, under the presidency of Donald Trump.

\begin{tabular}{|c|c|c|c|c|c|c|c|c|c|c|c|}
\hline & AEI & $\begin{array}{l}\text { Cato } \\
\text { Institute }\end{array}$ & CEI & Heartland & $\begin{array}{l}\text { Heritage } \\
\text { Foundation }\end{array}$ & $\begin{array}{l}\text { Hoover } \\
\text { Institution }\end{array}$ & $\begin{array}{l}\text { Manhattan } \\
\text { Institute }\end{array}$ & $\begin{array}{l}\text { Niskanen } \\
\text { Center }\end{array}$ & $\begin{array}{l}\text { Reason } \\
\text { Foundation }\end{array}$ & R-Street & Total \\
\hline $\begin{array}{r}\text { Before } \\
1997\end{array}$ & 0 & 0 & 0 & 0 & 0 & 0 & 0 & 0 & 0 & 0 & 0 \\
\hline $1997-2001$ & 0 & 0 & 0 & 0 & 0 & 1 & 0 & 0 & 1 & 0 & 2 \\
\hline 2001-2006 & 2 & 0 & 1 & 0 & 0 & 0 & 0 & 0 & 0 & 0 & 3 \\
\hline 2006-2009 & 5 & 1 & 0 & 3 & 0 & 2 & 0 & 0 & 0 & 0 & 11 \\
\hline 2009-2017 & 27 & 7 & 7 & 7 & 1 & 5 & 6 & 1 & 4 & 4 & 69 \\
\hline $\begin{array}{r}2017- \\
\text { November } \\
2018\end{array}$ & 1 & 0 & 0 & 6 & 0 & 2 & 0 & 3 & 2 & 1 & 15 \\
\hline Total & 35 & 8 & 8 & 16 & 1 & 10 & 6 & 4 & 7 & 5 & 100 \\
\hline
\end{tabular}

Table 2: timing of online publications about geoengineering by major US conservative and libertarian think tanks

What my analysis shows is that, before 2001, SRM was almost never discussed in the public statements and recommendations of the 10 think tanks under study (only twice before 1997, and three times between 1997 and 2001). The publication of Crutzen's article really appears to have been a watershed moment since, in the last two years of George W. Bush's presidency, the topic came up eleven times while the Obama era saw a significant uptick in interest with 69 occurrences. The election of Donald Trump has not led to a reduction in the pace of publications. From early 2017 to the end of 2018, SRM was raised 15 times by five different think tanks. It is therefore safe to argue that after the publication of Paul Crutzen's 2006 article, SRM became a regular, though marginal, feature of the climate deliberations of several prominent conservative and libertarian think tanks.

Finally, I have looked at the proportions of publications and references that were favorable, unfavorable, and neutral with regards to SRM.

Statements in favor Statements opposed Neutral statements of SRM to SRM

\begin{tabular}{|l|l|l|l|}
\hline AEI & 25 & 0 & 10 \\
Cato Institute & 4 & 3 & 1 \\
\cline { 2 - 5 } Heartland & 7 & 0 & 1 \\
Heritage Foundation & 3 & 3 & 10 \\
Hoover Institution & 7 & 0 & 1 \\
Manhattan Institute & 4 & 1 & 2 \\
\cline { 2 - 5 } & & 0 & 2 \\
\cline { 2 - 5 } & & &
\end{tabular}

Table 3: proportions of publications and references that were favorable, unfavorable, and neutral with regards to SRM between 1996 and November 2018 

funding for SRM while unfavorable references reflected unequivocal opposition. Neutral references point to statements in which SRM was mentioned and referenced without the author of the publication voicing an opinion about its desirability either way. My analysis reveals that very few conservative and libertarian experts have taken a stand against SRM so far. Out of the 100 references to SRM on the websites of the ten think tanks under study, only seven can be characterized as hostile, three of them by Cato experts, three by Heartland experts, and one by a Hoover Institution scholar. It should also be noted that all of those statements were made during the obama presidency and that I have been unable to identify a single hostile statement since the beginning of the Trump administration. By contrast, a clear majority of references to SRM (64 out of 100) contained support for funding research, while SRM was also mentioned 29 times in a neutral fashion.

the notion that free-market conservatives and libertarian experts have rallied behind geoengineering with a view to marginalizing other, less ideologically and economically convenient, policy options like carbon taxes and onerous regulations. In order to make his case, Clive Hamilton emphasizes the role performed by the American Enterprise Institute but also affirms that "the Exxon-funded Heartland Institute the leading denialist organization that has hosted a series of conferences at which climate science is denounced as a hoax and a communist conspiracy has enthusiastically endorsed geoengineering as the answer to the problem that does not exist." ${ }^{56}$ Likewise, Jack Stilgoe references Heritage, AEI, and Heartland as three think tanks that raised the issue of SRM "enthusiastically" after Crutzen published his article in $2006 .{ }^{57}$ Eli Kintisch also singles out AEI as a major freemarket institution in favor of SRM along with the physicist Edward Teller, the then Wall Street Journal editor Bret Stephens, and the Danish statistician Bjorn Lomborg. ${ }^{58}$

Although AEI's support for SRM is a matter of public record and is corroborated by my analysis, the case of Heartland is a lot less clear and self-evident. The Heartland Institute has no official position on SRM and this topic is almost never raised in its online publications. Hamilton's, Kintisch's, and Stilgoe's account of Heartland's position appears to rely on statements by a policy expert named David Schnare who gave a talk in support of SRM at the first International Conference on Climate Change (ICCC-1) hosted by Heartland in 2008. Heartland's website also features an online article by Alexander Cockburn who pours scorn on the idea of climate engineering. ${ }^{59}$ As for Heritage, in late 2018, it had no position on SRM. In a private email on October 302018 , Heritage's Nick Loris confirmed it although he wrote that he found "it to be a more intriguing, far more cost-effective solution to mitigate warming than re-engineering the global energy landscape" before warning about "the unintended consequences geoengineering may produce." ${ }^{60} \mathrm{He}$ also cited limited time and resources to justify Heritage's silence on SRM.

No doubt SRM has elicited favorable attention among a few conservative and libertarian experts but it seems too early to affirm that free-market conservatives have enthusiastically fallen behind SRM. Right now the most frequent recommendation made by those think tanks consists in arguing that mitigation policies would be ineffective, impractical, and economically devastating, and that, consequently, the US government would be well-advised to focus on spurring economic growth so that American people will be able to afford adaptation measures and strategies when faced 
with the negative consequences of climate change. ${ }^{61}$ In the larger context of freemarket policy advice those positions and recommendations are vastly more visible and common than SRM.

Overemphasizing the importance of SRM for conservative and libertarian experts and exaggerating the degree of their support for it will not help our understanding of their attitudes regarding climate engineering and, more broadly, regarding climate policy. In 2017 the environmentalist group ETC, which has been steadfast in its opposition to geoengineering, tried to link the Trump administration to SRM. In order to do so, it mentioned David Schnare (who briefly worked for Donald Trump's EPA), Newt Gingrich, and Rex Tillerson who have ties with the Trump administration and have on occasions made statements favorable to SRM. ${ }^{62}$ Here again, those links are not insignificant but they are certainly insufficient to suggest that the Trump administration is likely to consider SRM seriously.

\section{A qualitative assessment of the state of the debate in the world of conservative and libertarian think tanks}

Finally it seems worth probing into the substance of what free-market experts have been writing about solar geoengineering. In this part, I will list and review all the arguments for and against SRM put forward by those experts. It is important to preface this list with a reminder that almost all those policy experts recognize that there are many risks and uncertainties attached to SRM. I begin with the arguments in favor of SRM research and moves on to the arguments against.

I have identified eight types of arguments in favor of SRM research.

The cost-effectiveness argument. This is undoubtedly the argument most often invoked by free-market experts. It is predicated on the assumption that the cost of truly effective mitigation policies will be simply too high and will outweigh the climate benefits. Consider, for instance, Lee Lane and Samuel Thernstrom's critique of the Kyoto protocol: "Kyoto's reach is too short, its grasp too weak and its costs too high." ${ }_{63}$ Instead of trying to reduce GHG emissions, they add, governments across the world should invest in research and development and in SRM research. ${ }^{64}$ In the wake of COP15 in Copenhagen, Diana Furchtgott-Roth at the Manhattan Institute insisted on the economic disadvantages of emissions reductions: "The approach would raise energy prices and costs of production, suppress wage and employment growth, and drive up prices of houses, home eating and cooling, cars, and other manufactured goods by raising production costs. It is a recipe for economic drag." She went on to promote geoengineering as an alternative to mitigation:

Successful geoengineering would permit earth's population to make far smaller reductions in carbon use and still slow or reverse global warming, but at a vastly lower cost. Just as critically, it would also buy time until more information is known about the process of global warming. ${ }^{65}$

Reason's Ronald Bailey has made a similar argument. ${ }^{66}$

The breathing-space argument. According to this view, a successful implementation of SRM would enable humanity to develop technologies that could hasten the decarbonization of the world economy while momentarily averting high levels of climate damages that are likely to materialize under business-as-usual scenarios. ${ }^{67} \mathrm{~A}$ 
corollary to this argument posits that SRM would make it possible to continue the task of reducing world poverty while exempting developing countries from being forced to adapt to climate change for several decades. ${ }^{68}$

The desperation argument. Proponents of this view usually warn that the task of decarbonizing the world economy is an impossible one because the process would inevitably be too complex, too slow, and too costly. From this perspective SRM is really all we have and is, therefore, our last, indeed our only viable option. In 2013, Lee Lane and J. Eric Bickel claimed that "the increasingly evident political bankruptcy of GHG control policies has driven much of the interest in SRM" ${ }^{69}$ and noted that this trend was also enhanced by the Great Recession of 2008, which made climate action less of a priority. ${ }^{70}$

The insurance-policy argument. Those holding this view claim that a crippling climate outcome under a business-as-usual scenario is possible but by no means certain so that instead of embarking on an onerous effort to reshape the world economy, rich nations like the US ought to buy some sort of an insurance policy in the form of SRM technologies. According to Lane and Bickel, SRM could "play an important risk management role." ${ }^{11}$ Alan Carlin, an economist whose work is often referenced by freemarket experts, takes a resolute stand against any sort of mitigation policies, which he dismisses as both futile and unnecessarily costly. Interestingly he downplays the likelihood of catastrophic climate change but concedes that SRM could turn out to be "a very low-cost insurance policy until and unless there is strong evidence that global temperatures are increasing (or decreasingly) rapidly." ${ }^{2}$ Writing for the Hoover Institution, former US Secretary of State George P. Schultz made a similar argument in a more guarded and cautious manner. ${ }^{73}$

The following arguments are a lot less common than the previous ones in the publications of free-market think tanks.

51 The survival-of-consumer-capitalism argument. In defense of SRM, Lee Lane writes that it would be "more consistent with individual liberty than are GHG controls" and "would require no government-imposed lifestyle changes." ${ }^{44}$ This remark seems to partly corroborate Clive Hamilton's suspicion that conservative support for geoengineering is but a strategy to salvage capitalism and the consumer society. Reason's Shikha Dalmia describes climate engineering as "a much easier task than coaxing or coercing people to give up their cars and children." ${ }^{75}$ In Reason magazine, Gregory Benford derides the environmentalist preference for strong mitigation policies as one predicated on 'a starkly Puritan ethic: 'Abstain, sinner!'."'76

52 The if-you-want-peace-prepare-for-war argument. R-Street's Josiah Neeley believes that, in a world where climate engineering is a real possibility, it is incumbent on the US government to be capable of deploying it in case other nations, especially major rivals like China or Russia, have developed their own capabilities to do so. Neeley's argument both addresses and reverses Stephen Gardiner's concern about the geopolitical risks inherent to SRM deployment by claiming that SRM is likely to be deployed sooner or later, regardless of the qualms US decision-makers may have about it. ${ }^{77}$

The this-is-the-anthropocene argument. Lee Lane and J. Eric Bickel make the point that human-made climate change is already a form of global-scale climate engineering but an uncontrolled and potentially very damaging one. In other words, our fossil fuel economy is already a gigantic exercise in geoengineering. It follows from that proposition that the notion that humanity may choose between a world with 
geoengineering and a world without it is an illusion. This leads Bickel and Lane to argue that the only choice we are faced with is between the haphazard and uncontrolled climate change we are already experiencing right now and a scientifically informed attempt at regulating the global climate..$^{78}$

This vision is echoed in Reason magazine. Gregory Benford presents the Earth as a spaceship that a tech-savvy and scientifically sophisticated humanity has a duty to control: "As we begin correcting for our inadvertent insults to Mother Earth, we should realize that it's forever. Once we become caretakers, we cannot stop." ${ }^{79}$ Benford's account of geoengineering foreshadowed Steward Brand's recognition that "humanity is now stuck with a planet stewardship role." 80

The silver-bullet argument. David Schnare, who seems to be an isolated case among freemarket experts, describes geoengineering as a panacea. Starting from the assumption that mitigation is a technical and economic dead end, he confidently asserts that carbon capture and solar radiation management will allow us to solve climate change in a cheap and effective way. ${ }^{81}$ It should be noted that the silver-bullet argument is an outlier in the publications of conservative and libertarian experts on the subject of geoengineering. Most of them acknowledge that SRM would probably be an imperfect solution. ${ }^{82}$

56 At the other end of the spectrum there is a much smaller variety of arguments against SRM, if only because very few free-market experts have taken a stand against SRM. I have identified four types of arguments, three of which overlap with those used by liberal critics of geoengineering.

The uncertainty argument. In the Cato journal, Berry et al. review several geoengineering technologies and then warn that "the solutions proposed above ignore the complexities of the decision that would need to be made- one which demands comprehension of a complex adaptive system like the environment." ${ }^{13}$ They rely on the work of Patrick J. Michaels and Paul C. Knappenberger to underscore the limitations of climate modeling. In another article published in the Cato Journal, Dholakia-Lehenbauer and Elliott seem equally skeptical of the power of human understanding to engineer the climate in an effective fashion and affirm that "confidence in the predictive power of simulation models leads to excessive confidence in the ability to predict future events." ${ }^{84}$ In that respect, those critics of geoengineering sound a lot more consistent than their colleagues who justify their support for SRM research thanks to highly speculative projections. As Stilgoe puts it, geoengineering is "an idea rather than a technology" ${ }^{85}$ so that SRM is heralded as a relatively inexpensive solution by its proponents, conservatives and libertarians included, only on the basis of mathematical models, the foundations of which are highly hypothetical. For instance, in a congressional testimony, Furchtgott-Roth highlighted the uncertainties which surround climate science, only to characterize SRM as cost-effective on the basis of highly speculative economic projections. ${ }^{86}$

58 The unintended-consequences argument. Paul C. Knappenberger of the Cato Institute warns that "geoengineering schemes seem like really bad ideas full of nasty consequences (unintentional and otherwise)." 87

59 The geopolitical-risks argument. Herb Lin of the Hoover Institution is highly ambivalent about geoengineering, first because of the many uncertainties surrounding its potential deployment and second because of the risk of destabilizing unilateral action. ${ }^{88}$ 
60 The denial argument. In the wake of the Copenhagen conference, Heartland's Alexander Cockburn lays out an impeccably consistent position: since humanmade climate change is not real, there is no reason to engage in geoengineering ${ }^{89}$ Cockburn's blog post is the only one of its kind I have been able to identify.

\section{Conclusion}

61 Although there are signs that institutions which have been instrumental in delaying action on climate change are considering geoengineering as a policy option to address climate change, it seems too early to say with confidence that support for geoengineering will become a standard position in conservative and libertarian circles. In late 2018 the standard position regarding climate change on the American right still consisted in opposing mitigation and prioritizing high rates of economic growth that will enable humankind to afford adaptation to climate change. Solar geoengineering remained a marginal topic of discussion among free-market experts and scholars.

Put simply, this article qualifies the claim made by several social scientists and journalists to the effect that solar geoengineering is fast becoming a powerful new weapon in the arsenal used by conservative and libertarian experts with a view to making the adoption of strong mitigation measures even more improbable than they already are. Analysis of data produced by prominent free-market think tanks suggests that this claim is premature. Solar geoengineering is being discussed in US free-market circles and might become more prominent as our climate predicament worsens but, until now, it has not been a key objective of those institutions.

63 It is notable, however, that most of those who did consider SRM tended to support funding for research often, though not always, as an alternative to mitigation policies. Hence the need for researchers to keep track of what is being said about SRM in the free-market think tanks that have a close relationship with the Republican party. It could also be instructive to find out whether elected officials start taking up their recommendations in favor of SRM funding.

64 So far, the influence of free-market think tanks on climate policy has been largely negative in that it has consisted in defeating or limiting the implementation of policy mechanisms intended for climate change mitigation, such as carbon taxes and emissions trading systems. Whether they are able to place SRM near the top of the policy agenda will help us determine how likely they are to marginalize mitigation even further. The important role performed by Crutzen's 2006 article, which led to a spike in the number of publications on SRM by free-market experts, does not seem to have any obvious precedent in the way in which free-market think tanks have approached climate policy historically. In order to gauge the ability of think tanks to turn marginal ideas into more mainstream policy proposals, it could be interesting to compare the attempts at promoting SRM described in this article with recent efforts by progressive think tanks like New Consensus to advertise the so-called Green New Deal. Although the chances of legislative success of the Green New Deal remain vanishingly small, there is no question that its proponents have already managed to capture the attention of the political class, both positively and negatively, in a way that SRM advocates have not until now. Looking into the reasons for this discrepancy could open promising avenues of research. 


\section{BIBLIOGRAPHY}

Abelson, Donald E. "It Seemed Like a Good Idea at the Time: Reflections on the Evolution of American Think Tanks." Canadian Review of American Studies 46, no. 1 (2016): 139-157.

American Geophysical Union. "Climate Intervention Requires Enhanced Research, Consideration of Societal and Environmental Impacts, and Policy Development." January 12, 2018. file:///E:/ geoengineering/r\%20sTREET/Climate-Intervention-Position-Statement-

Final-2018-1\%20American\%20Geophysical\%20Union.pdf.

Appell, David. "Strange Bedfellows? Climate Change Denial and Support for Geoengineering." Yale Climate Connections, October 10, 2013. https://www.yaleclimateconnections.org/2013/10/ strange-bedfellows-climate-change-denial-and-support-for-geoengineering/.

Asafu-Adjaye, John, Linus Blomqvist, Stewart Brand, Barry Brook, Ruth Defries, Erle Ellis, Christopher Foreman, David Keith, Martin Lewis, Mark Lynas, Ted Nordhaus, Roger Pielke Jr., Rachel Pritzker, Joyashree Roy, Mark Sagoff, Michael Shellenberger, Robert Stone, and Peter Teague. “An Ecomodernist Manifesto.” Ecomodernism.org, April 2015. http:// www.ecomodernism.org/manifesto-english/.

Bailey, Ronald. “An Emergency Cooling System for the Planet." Reason Foundation, June 10, 2008. https://reason.com/archives/2008/06/10/an-emergency-cooling-system-fo.

Benford, Gregory. “Climate Controls.” Reason Foundation, November 1997. https://reason.com/ archives/1997/11/01/climate-controls.

Berry, Brian J.L., Jayshree Bihari, and Euel Elliott. "The Limits of Knowledge and the Climate Change Debate." Cato Journal 36, no. 3 (2016): 589-610.

Bonneuil, Christophe, and Jean-Baptiste Fressoz. L'événement Anthropocène: la terre, l'histoire et nous. Paris: Éditions du Seuil, 2013.

Bourg, Dominique, and Gerald Hess. « La géo-ingénierie : réduction, adaptation et scénario du désespoir. » Natures Sciences Sociétés 18, no. 3 (2010): 298-304.

Brand, Stewart. Whole Earth Discipline. London: Atlantic Books, 2010.

Burns, Wil C.G. "Climate Geoengineering: Solar Radiation Management and its Implications for Intergenerational Equity." In Climate Change Geoengineering: Philosophical Perspectives, Legal Issues and Governance Frameworks, edited by Wil C.G. Burns and Andrew L. Strauss, 81-114. New York: Cambridge University Press, 2013.

Burstein, Paul. American Public Opinion, Advocacy, and Policy in Congress: What the Public Wants and What It Gets. New York: Cambridge University Press, 2014.

Caldeira, Ken, and David Keith. "The Need for Climate Engineering Research." Issues in Science and Technology 27, no. 1 (2010): 57-62.

Carlin, Alan. “A Multidisciplinary, Science-Based Approach to the Economics of Climate Change." International Journal of Environmental Research and Public Health 8 (2011): 985-1031.

Cato Institute. Cato Handbook for Policymakers. Washington DC: Cato Institute, 2017. https:// www.cato.org/cato-handbook-policymakers/cato-handbook-policy-makers-8th-edition-2017.

Charbonnier, Pierre. «L'ambition démocratique à l'âge de l'anthropocène. » Esprit, 12 (2015): $34-45$. 
Cockburn, Alexander. "Anthropogenic Global Warming is a Farce." Heartland Institute. December 24, 2009. https://www.heartland.org/publications-resources/publications/anthropogenicglobal-warming-is-a-farce.

Collomb, Jean-Daniel. “A Worthy Heir: Donald Trump, the Republican Party and Climate Change.” Revue LISA/LISA e-journal XVI, no. 2 (2018). https://journals.openedition.org/lisa/9941.

Committee on Geoengineering Climate. "Climate Intervention: Reflecting Sunlight to Cool Earth." Washington DC: The National Academies of Sciences, 2015. https://www.nap.edu/read/18988/ chapter/1.

Competitive Enterprise Institute. Energy and Environment: Free to Prosper: A Pro-Growth Agenda for the 115th Congress. Washington DC: Competitive Enterprise Institute, 2016. https://cei.org/ agendaforcongress-2017.

Corner Adam, Nick Pidgeon, and Karen Parkhill. "Perception of Geoengineering: Public Attitudes, Stakeholder Perspectives, and the Challenge of 'Upstream' Engagement." WIREs Climate Change 3, no. 5 (2011): 451-466.

Crutzen, Paul. “Albedo Enhancement by Stratospheric Injections: A Contribution to Resolve Policy Dilemma." Climatic Change 77 (2006): 211-219.

Dalmia, Shikha. “Why the Left Can't Solve Global Warming." Reason Foundation, July 28, 2017. https://reason.com/archives/2017/07/28/why-the-left-cant-solve-global-warming.

Dunlap, Riley E., and Aaron M. McCright. "Challenging Climate Change: The Denial Countermovement." In Climate Change and Society: Sociological Perspectives, edited by Riley E. Dunlap and Robert J. Brulle, 300-332. New York: Oxford University Press, 2015.

Ellison, Katherine. "Why Climate Change Skeptics Are Backing Geoengineering." Wired magazine, March 28, 2018. https://www.wired.com/story/why-climate-change-skeptics-are-backinggeoengineering/.

Dholakia-Lehenbauer, Kruti, and Euel W. Elliott. "Decisionmaking, Risk, and Uncertainty: An Analysis of Climate Change Policy." Cato Journal 32, no. 3 (2012): 539-556.

ETC. “The Trump administration a Geoengineering Administration?" ETC Group Briefing, March 27, 2017. http://www.etcgroup.org/sites/www.etcgroup.org/files/files/

etc_briefing_the_trump_administration_-_a_geoengineering_administration.pdf.

Fleming, James R. Fixing the Sky: The Checkered History of Weather and Climate Control. New York: Columbia University Press, 2010.

Furchtgott-Roth, Diana. “Climate Change: Another Option.” Manhattan Institute, December 10, 2009. https://www.manhattan-institute.org/html/climate-change-another-option-2232.html. Furchtgott-Roth, Diana. "Testimony of Diana Furchtgott-Roth on Climate Change." Manhattan Institute, July 18, 2013. https://www.manhattan-institute.org/html/testimony-diana-furchtgottroth-climate-change-6091.html.

Gardiner, Stephen M. "The Desperation Argument for Geoengineering." Political Science and Politics 46, no. 1 (2013): 28-33.

Gingrich, Newt. "Stop the Green Pig: Defeat the Boxer-Warner-Lieberman Green Pork Bill Capping American Jobs and Trading America's Future." Human Events, June 3, 2008. http:// humanevents.com/2008/06/03/stop-the-green-pig-defeat-the-boxerwarnerlieberman-greenpork-bill-capping-american-jobs-and-trading-americas-future/. 
Hamilton, Clive. Earthmasters: The Dawn of the Age of Climate Engineering. New Haven: Yale University Press, 2013.

Hayward, Steven F. “Conservatism and Climate Science.” Issues in Science and Technology 30, no. 3 (2014): 52-57.

Heritage Foundation. Blueprint for Reform: A Comprehensive Policy Agenda for a New Administration in 2017. Washington DC: Heritage Foundation, 2016. https://www.heritage.org/budget-andspending/report/blueprint-reform-comprehensive-policy-agenda-new-administration-2017.

Horton, Joshua B. “Geoengineering and the Myth of Unilateralism.” In Climate Change Geoengineering: Philosophical Perspectives, Legal Issues and Governance Frameworks, edited by Wil C.G. Burns and Andrew L. Strauss, 168-181. New York: Cambridge University Press, 2013.

Hulme, Mike. Can Science Fix Climate Science? Cambridge: Polity, 2014.

Huttunen Sanna, Emmi Skyten, and Mikael Hilden. "Emerging Policy Perspectives on Geoengineering: An International Comparison." The Anthropocene Review 2, no. 1 (2015): 14-32.

Iklé, Fred C., and Lowell Wood. "Sunscreen for Planet Earth.” Hoover Institution, June 10, 2008. https://www.hoover.org/research/sunscreen-planet-earth.

Intergovernmental Panel on Climate Change. Climate Change 2014 Synthesis Report Summary for Policymakers, 2014. https://www.ipcc.ch/site/assets/uploads/2018/02/AR5_SYR_FINAL_SPM.pdf. Intergovernmental Panel on Climate Change. Summary for Policymakers, 2018. https:// templatelab.com/ipcc-special-report-1.5/.

Jamieson, Dale. Reason in a Dark Time: Why the Struggle Against Climate Change Failed and What it Means for our Future. New York: Oxford University Press, 2014.

Kahan, Dan M., Hank Jenkins-Smith, Tor Tarantola, Carol L. Silva, and Donald Braman. "Geoengineering and Climate Change Polarization: Testing a Two-Channel Model of Science Communication." Annals of the American Academy of Political and Social Science 658, no. 1 (2015): 192-222.

Keith, David. A Case for Climate Engineering. Cambridge: The MIT Press, 2013.

Kintisch, Eli. Hack the Planet: Science's Best Hope or Worst Nightmare for Averting Catastrophe. Hoboken, NJ: John Wiley \& Sons, 2010.

Knappenberger, Paul C. "Geo-Engineering the Climate? A Geo-Bad Idea." Cato Institute, November 11, 2014. https://www.cato.org/blog/geo-engineering-climate-geo-bad-idea.

Lane, Lee. Strategic Policy Options for the Bush Administration Climate Policy. Washington DC: AEI Press, 2006.

Lane, Lee, and Samuel Thernstrom. "A New Direction for US Climate Policy: Credible Alternatives to Kyoto." American Enterprise Institute, Environmental Policy Outlook, nº 1, 2007. https:// www.aei.org/publication/a-new-direction-for-bush-administration-climate-policy/.

Lane, Lee, and J. Eric Bickel. “Climate Change, Climate Engineering R\&D.” Copenhagen Consensus, Challenge Paper, 2012. http://www.schrogl.com/03ClimateGeo/DOKUMENTE/ 201_BICKEL_LANE_CLIMATE_CHANGE_2012.pdf.

Lane, Lee, and J. Eric Bickel. An Analysis of Climate Engineering as a Response to Climate Change. Fredericksburg, Denmark: Copenhagen Consensus on Climate, 2009. http://www.aei.org/wpcontent/uploads/2011/10/AP-Climate-Engineering-Bickel-Lane-v.3.0.pdf. 
Lane, Lane, and J. Eric Bickel. "Solar Radiation Management: An Evolving Climate Policy Option." American Enterprise Institute, May 1, 2013. http://www.aei.org/publication/solar-radiationmanagement-an-evolving-climate-policy-option/.

Larrère, Catherine. « Anthropocène : le nouveau grand récit. » Esprit 12 (2015): 46-55.

Lin, Herb. "Large-scale geoengineering and threats to national security." Lawfare, October 31, 2015. https://www.lawfareblog.com/large-scale-geoengineering-and-threats-national-security.

Lovelock, James. “A Geophysiologist's Thoughts on Geoengineering." Philosophical Transactions: Mathematical, Physical and Engineering Sciences 366, no. 1882 (2008): 3883-3890.

Mahajan, Aseem, Dustin Tingley, and Gernot Wagner. "Fast, Cheap, and Imperfect? US Public Opinion about Solar Geoengineering." Environmental Politics 6 (2018).

McGann, James G. Global Go To Think Tank Index Report. 12 (2017).

Mercer Ashley M., David W. Keith, and Jacqueline D. Sharp. "Public Understanding of Solar Radiation Management.” Environmental Research Letters 6, no. 4, (2011): 044006.

Michaelson, Jay. “Geoengineering and Climate Management.” In Climate Change Geoengineering: Philosophical Perspectives, Legal Issues and Governance Frameworks, edited by Wil C.G. Burns and A.L. Strauss, 81-114. New York: Cambridge University Press, 2013.

Mooney, Chris. "Rex Tillerson's View of Climate Change: It's an 'Engineering Problem'.” The Washington Post, December 14, 2016. https://www.washingtonpost.com/news/energyenvironment/wp/2016/12/13/rex-tillersons-view-of-climate-change-its-just-an-engineeringproblem/?utm_term=.6d7110a1cd1c.

Morton, Oliver. The Planet Remade: How Geoengineering Could Change the World. Princeton University Press, 2015.

Murphy, Robert P. “The Benefits of Procrastination: The Economics of Geo-Engineering.” The Library of Economics and Liberty, December 7, 2009. https://www.econlib.org/library/Columns/ y2009/Murphygeoengineering.html.

Neeley, Josiah. "Geoengineering: The Cold War on Global Warming." R-Street, February 27, 2015. https://www.rstreet.org/2015/02/27/geoengineering-the-cold-war-on-global-warming/.

Pinker, Steven. Enlightenment Now: The Case for Reason, Science, Humanism, and Progress. New York: Viking, 2018.

Rich, Andrew. Think Tanks and Public Policy Advice in the United States: Academics, Advisers and Advocates. New York: Routledge, 2007.

Robock, Alan. “Twenty Reasons Geoengineering May Be a Bad Idea." Bulletin of the Atomic Scientists 64, no. 2 (2008): 14-18.

Schäfer, Stefan, and Sean Low. "Asilomar Moments: Formative Framings in Recombinant DNA and Solar Climate Engineering Research." Philosophical Transactions: Mathematical, Physical and Engineering Sciences 372, no. 2031 (2014): 1-15.

David W. Schnare. "Climate Change and the Uncomfortable Middle Ground: The Geoengineering and 'No Regrets' Policy Alternative." The Thomas Jefferson Institute for Public Policy, March 2008. http://www.thomasjeffersoninst.org/pdf/articles/Schnare_speech_2.pdf .

Schneider, Stephen H. “Geoengineering: Could we or Should we Make it Work?" Philosophical Transactions: Mathematical, Physical and Engineering Sciences 366, no. 1882 (2008): 3857-3858. 
Schultz, George P. “The Past Must Not Be Prologue.” The Hoover Institution, December 9, 2008. https://www.hoover.org/research/past-must-not-be-prologue.

Schwartz, Peter, and Doug Randall. "An Abrupt Climate Change and its Implications for United States National Security.” 2003. https://eesc.columbia.edu/courses/v1003/readings/ Pentagon.pdf.

Shepherd, John G. "Geoengineering the Climate: An Overview and Update." Philosophical Transactions: Mathematical, Physical and Engineering Sciences 370, no. 1974 (2012): 4166-4175.

Singer, Peter. One World Now: The Ethics of Globalization. New Haven: Yale University Press, 2016.

Stahl, Jason. Right Moves: The Conservative Think Tank in American Political Culture since 1945. Chapel Hill: The University of North Carolina Press, 2016.

Stilgoe, Jack. Experiment Earth: Responsible Innovation in Geoengineering. London: Earthscan, 2015.

Thernstrom, Samuel. “Engineering the Climate." American Enterprise Institute, January 14, 2009. http://www.aei.org/publication/engineering-the-climate-2/.

\section{NOTES}

1. Chris Mooney, "Rex Tillerson's View of Climate Change: It's an 'Engineering Problem,", The Washington Post, December 14, 2016, https://www.washingtonpost.com/ news/energy-environment/wp/2016/12/13/rex-tillersons-view-of-climate-change-itsjust-an-engineering-problem/?utm_term=.6d7110a1cd1c.

2. John G. Shepherd, "Geoengineering the Climate: An Overview and Update," Philosophical Transactions: Mathematical, Physical and Engineering Sciences, 370, no. 1974 (2012): 4166-4175.

3. Ibid., 4166.

4. Sanna Huttunen, Emmi Skyten, and Mikael Hilden, "Emerging Policy Perspectives on Geoengineering: An International Comparison," The Anthropocene Review 2, no. 1 (2015): 18.

5. Clive Hamilton, Earthmasters: The Dawn of the Age of Climate Engineering (New Haven: Yale University Press, 2013), 18.

6. Ibid., 90.

7. Ibid., 119.

8. Dominique Bourg and Gérald Hess, « La géo-ingénierie: réduction, adaptation et scénario du désespoir, » Natures Sciences Sociétés 18, no. 3 (2010): 300. Christophe Bonneuil and Jean-Baptiste Fressoz, L'événement Anthropocène : la terre, l'histoire et nous (Paris: Éditions du Seuil, 2013), 102-107. Catherine Larrère, « Anthropocène: le nouveau grand récit, » Esprit 12 (2015): 50.

9. Eli Kintisch, Hack the Planet: Science's Best Hope or Worst Nightmare for Averting Catastrophe (Hoboken, NJ: John Wiley \& Sons, 2010), 199.

10. David Appell, "Strange Bedfellows? Climate Change Denial and Support for Geoengineering," Yale Climate Connections, October 10, 2013, https:// www.yaleclimateconnections.org/2013/10/strange-bedfellows-climate-change-denialand-support-for-geoengineering/. Pierre Charbonnier, «L'ambition démocratique à l'âge de l'anthropocène, » Esprit 12 (2015): 34-35. Katherine Ellison, "Why Climate Change Skeptics Are Backing Geoengineering," Wired magazine, March 28, 2018, 
https://www.wired.com/story/why-climate-change-skeptics-are-backinggeoengineering/.

11. Newt Gingrich, "Stop the Green Pig: Defeat the Boxer-Warner-Lieberman Green Pork Bill Capping American Jobs and Trading America's Future," Human Events, June 3, 2008, http://humanevents.com/2008/06/03/stop-the-green-pig-defeat-theboxerwarnerlieberman-green-pork-bill-capping-american-jobs-and-trading-americasfuture/.

12. Lee Lane and J. Eric Bickel, "Solar Radiation Management: An Evolving Climate Policy Option," American Enterprise Institute, May 1, 2013, http://www.aei.org/ publication/solar-radiation-management-an-evolving-climate-policy-option/. 13. Ashley M. Mercer., David W. Keith, and Jacqueline D. Sharp, "Public Understanding of Solar Radiation Management," Environmental Research Letters 6, no. 4, (2011): 8. Adam Corner, Nick Pidgeon, and Karen Parkhill, "Perception of Geoengineering: Public Attitudes, Stakeholder Perspectives, and the Challenge of 'Upstream' Engagement," WIREs Climate Change 3, no. 5 (2011): 454. Aseem Mahajan, Dustin Tingley, and Gernot Wagner, "Fast, Cheap, and Imperfect? US Public Opinion about Solar Geoengineering," Environmental Politics 6 (2018): 6.

14. Paul Burstein, American Public Opinion, Advocacy, and Policy in Congress: What the Public Wants and What It Gets (New York: Cambridge University Press, 2014), 68-70.

15. Jean-Daniel Collomb, "A Worthy Heir: Donald Trump, the Republican Party and Climate Change," Revue LISA/LISA e-journal XVI, no. 2 (2018), https://

journals.openedition.org/lisa/9941.

16. Andrew Rich, Think Tanks and Public Policy Advice in the United States: Academics, Advisers and Advocates (New York: Routledge, 2007), 6.

17. Donald E. Abelson, "It Seemed Like a Good Idea at the Time: Reflections on the Evolution of American Think Tanks," Canadian Review of American Studies 46, no. 1 (2016): 141.

18. Jason Stahl, Right Moves: The Conservative Think Tank in American Political Culture since 1945 (Chapel Hill: The University of North Carolina Press, 2016): 37.

19. Ibid., 92.

20. James G. McGann, Global Go To Think Tank Index Report, 12 (2017): 55-56.

21. Riley E. Dunlap and Aaron M. McCright, "Challenging Climate Change: The Denial Countermovement," in Climate Change and Society: Sociological Perspectives, ed. Riley E. Dunlap and Robert J. Brulle, 300-332 (New York: Oxford University Press, 2015), 312.

22. Mike Hulme, Can Science Fix Climate Science? (Cambridge: Polity, 2014), 7-8.

23. Ibid., 6.

24. James R. Fleming, Fixing the Sky: The Checkered History of Weather and Climate Control (New York: Columbia University Press, 2010), 165-188.

25. Peter Schwartz and Doug Randall, "An Abrupt Climate Change and its Implications for United States National Security," 2003, https://eesc.columbia.edu/courses/v1003/ readings/Pentagon.pdf.

26. Hamilton, Earthmasters, 15.

27. Oliver Morton, The Planet Remade: How Geoengineering Could Change the World (Princeton University Press, 2015), 154.

28. Committee on Geoengineering Climate, "Climate Intervention: Reflecting Sunlight to Cool Earth," (Washington DC: The National Academies of Sciences, 2015), 8, https:// www.nap.edu/read/18988/chapter/1. 
29. American Geophysical Union, "Climate Intervention Requires Enhanced Research, Consideration of Societal and Environmental Impacts, and Policy Development," January 12, 2018, file:///E:/geoengineering/r\%20sTREET/Climate-InterventionPosition-Statement-Final-2018-1\%20American\%20Geophysical\%20Union.pdf.

30. Intergovernmental Panel on Climate Change, Summary for Policymakers, 2018, 14-15, https://report.ipcc.ch/sr15/pdf/sr15_spm_final.pdf.

31. Stefan Schäfer and Sean Low, "Asilomar Moments: Formative Framings in Recombinant DNA and Solar Climate Engineering Research," Philosophical Transactions: Mathematical, Physical and Engineering Sciences 372, no. 2031 (2014): 11.

32. Ken Caldeira and David Keith, "The Need for Climate Engineering Research," Issues in Science and Technology 27, no. 1 (2010): 57-62.

33. Stephen H. Schneider, "Geoengineering: Could we or Should we Make it Work?," Philosophical Transactions: Mathematical, Physical and Engineering Sciences 366, no. 1882 (2008): 3857-3858. Shepherd, "Geoengineering," 4116.

34. Caldeira, "Need," 58.

35. Jay Michaelson, "Geoengineering and Climate Management" in: Climate Change Geoengineering: Philosophical Perspectives, Legal Issues and Governance Frameworks, ed. Wil C.G. Burns and A.L. Strauss, 81-114 (New York: Cambridge University Press, 2013).

36. Morton, Planet, 9.

37. David Keith, A Case for Climate Engineering (Cambridge: The MIT Press, 2013), 137.

38. Morton, Planet, 9.

39. John Asafu-Adjaye, et al., “An Ecomodernist Manifesto," Ecomodernism.org, April 2015, http://www.ecomodernism.org/manifesto-english/.

40. Stewart Brand, Whole Earth Discipline (London: Atlantic Books, 2010), 275-302.

41. Steven Pinker, Enlightenment Now: The Case for Reason, Science, Humanism, and Progress (New York: Viking, 2018), 152-153.

42. Peter Singer, One World Now: The Ethics of Globalization (New Haven: Yale University Press, 2016), 64-68.

43. Alan Robock, "Twenty Reasons Geoengineering May Be a Bad Idea," Bulletin of the Atomic Scientists 64, no. 2 (2008): 14-18. Huttunen, Skyten, and Hilden, "Emerging Policy," 21. Dale Jamieson, Reason in a Dark Time: Why the Struggle Against Climate Change Failed and What it Means for our Future (New York: Oxford University Press, 2014):

220-228.

44. James Lovelock, “A Geophysiologist's Thoughts on Geoengineering," Philosophical Transactions: Mathematical, Physical and Engineering Sciences 366, no. 1882 (2008): 3888.

45. Hulme, Science, 98-99.

46. Schneider, "Geoengineering," 3847.

47. Dan M. Kahan, et al., "Geoengineering and Climate Change Polarization: Testing a Two-Channel Model of Science Communication," Annals of the American Academy of Political and Social Science 658, no. 1 (2015): 205-206.

48. Wil C.G. Burns, "Climate Geoengineering: Solar Radiation Management and its Implications for Intergenerational Equity," in: Climate Change Geoengineering: Philosophical Perspectives, Legal Issues and Governance Frameworks, ed. Wil C.G. Burns and Andrew L. Strauss, 81-114 (New York: Cambridge University Press, 2013), 208-213. 49. Keith, Case, 77-118.

50. Jack Stilgoe, Experiment Earth: Responsible Innovation in Geoengineering, (London: Earthscan, 2015): 13.

51. Keith, Case, 156. 
52. Stephen M. Gardiner, "The Desperation Argument for Geoengineering," Political Science and Politics 46, no. 1 (2013): 31.

53. Schneider, “Geoengineering," 3857.

54. Joshua Horton, "Geoengineering and the Myth of Unilateralism," in: Climate Change Geoengineering: Philosophical Perspectives, Legal Issues and Governance Frameworks, ed. Wil C.G. Burns and Andrew L. Strauss, 168-181 (New York: Cambridge University Press, 2013), 172-173.

55. Steven F. Hayward, "Conservatism and Climate Science," Issues in Science and Technology 30, no. 3 (2014): 54.

56. Hamilton, Earthmasters, 90.

57. Stilgoe, Experiment, 107.

58. Kintisch, Hack, chapter 10.

59. Alexander Cockburn, "Anthropogenic Global Warming is a Farce," Heartland Institute, December 24, 2009, https://www.heartland.org/publications-resources/ publications/anthropogenic-global-warming-is-a-farce.

60. Private email from Nick Loris to Jean-Daniel Collomb, October 30, 2018.

61. Competitive Enterprise Institute, Energy and Environment: Free to Prosper: A Pro-Growth Agenda for the 115th Congress, (Washington DC: Competitive Enterprise Institute, 2016), 64-68, https://cei.org/agendaforcongress-2017. Heritage Foundation, Blueprint for Reform: A Comprehensive Policy Agenda for a New Administration in 2017, (Washington DC: Heritage Foundation, 2016), 21-25, https://www.heritage.org/budget-and-spending/ report/blueprint-reform-comprehensive-policy-agenda-new-administration-2017. Cato Institute, Cato Handbook for Policymakers, (Washington DC: Cato Institute, 2017), 627-636, https://www.cato.org/cato-handbook-policymakers/cato-handbook-policymakers-8th-edition-2017.

62. ETC, "The Trump administration a Geoengineering Administration?," ETC Group Briefing, March 27, 2017, http://www.etcgroup.org/sites/www.etcgroup.org/files/ files/etc_briefing_the_trump_administration_-_a_geoengineering_administration.pdf. 63. Lee Lane and Samuel Thernstrom, "A New Direction for US Climate Policy: Credible Alternatives to Kyoto," American Enterprise Institute, Environmental Policy Outlook, n¹, 2007, 2, https://www.aei.org/publication/a-new-direction-for-bush-administrationclimate-policy/.

64. Ibid., 3-4.

65. Diana Furchtgott-Roth, “Climate Change: Another Option," Manhattan Institute, December 10, 2009, https://www.manhattan-institute.org/html/climate-changeanother-option-2232.html.

66. Ronald Bailey, "An Emergency Cooling System for the Planet," Reason Foundation, June 10, 2008, https://reason.com/archives/2008/06/10/an-emergency-coolingsystem-fo.

67. Ibid. Fred C. Iklé and Lowell Wood, "Sunscreen for Planet Earth," Hoover Institution, June 10, 2008, https://www.hoover.org/research/sunscreen-planet-earth. Samuel Thernstrom, "Engineering the Climate," American Enterprise Institute, January 14, 2009, http://www.aei.org/publication/engineering-the-climate-2/. 68. Robert P. Murphy, "The Benefits of Procrastination: The Economics of GeoEngineering," The Library of Economics and Liberty, December 7, 2009, https:// www.econlib.org/library/Columns/y2009/Murphygeoengineering.html. 69. Lane and Bickel, "Solar," 20.

70. Ibid., 9 . 
71. Lee Lane and Eric J. Bickel, “Climate Change, Climate Engineering R\&D,” Copenhagen Consensus, Challenge Paper, 2012, 4, http://www.schrogl.com/03ClimateGeo/ DOKUMENTE/201_BICKEL_LANE_CLIMATE_CHANGE_2012.pdf.

72. Alan Carlin, "A Multidisciplinary, Science-Based Approach to the Economics of Climate Change," International Journal of Environmental Research and Public Health 8 (2011): 1017.

73. George P. Schultz, "The Past Must Not Be Prologue," The Hoover Institution, December 9, 2008, https://www.hoover.org/research/past-must-not-be-prologue.

74. Lee Lane, Strategic Policy Options for the Bush Administration Climate Policy, (Washington DC: AEI Press, 2006), 73

75. Shikha Dalmia, "Why the Left Can't Solve Global Warming," Reason Foundation, July 28, 2017, https://reason.com/archives/2017/07/28/why-the-left-cant-solve-globalwarming.

76. Gregory Benford, “Climate Controls," Reason Foundation, November 1997, https:// reason.com/archives/1997/11/01/climate-controls.

77. Josiah Neeley, "Geoengineering: The Cold War on Global Warming," R-Street, February 27, 2015, https://www.rstreet.org/2015/02/27/geoengineering-the-cold-waron-global-warming/.

78. Lane and Bickel, "Climate Change," 4.

79. Benford, "Climate".

80. Steward Brand, Whole Earth Discipline, (London: Atlantic Books, 2010): 275.

81. David W. Schnare, "Climate Change and the Uncomfortable Middle Ground: The Geoengineering and 'No Regrets' Policy Alternative," The Thomas Jefferson Institute for Public Policy, March 2008, http://www.thomasjeffersoninst.org/pdf/articles/ Schnare_speech_2.pdf .

82. Lee Lane and J. Eric Bickel, An Analysis of Climate Engineering as a Response to Climate Change, (Fredericksburg, Denmark: Copenhagen Consensus on Climate, 2009): 49, http://www.aei.org/wp-content/uploads/2011/10/AP-Climate-Engineering-BickelLane-v.3.0.pdf.

83. Brian J.L. Berry, Jayshree Bihari, and Euel Elliott, "The Limits of Knowledge and the Climate Change Debate," Cato Journal 36, no. 3 (2016): 600.

84. Kruti Dholakia-Lehenbauer and Euel W. Elliott, "Decisionmaking, Risk, and Uncertainty: An Analysis of Climate Change Policy," Cato Journal, 32, no. 3 (2012): 554.

85. Stilgoe, Experiment, 87.

86. Diana Furchtgott-Roth, “Testimony of Diana Furchtgott-Roth on Climate Change," Manhattan Institute, July 18, 2013, https://www.manhattan-institute.org/html/ testimony-diana-furchtgott-roth-climate-change-6091.html.

87. Paul C. Knappenberger, "Geo-Engineering the Climate? A Geo-Bad Idea," Cato Institute, November 11, 2014, https://www.cato.org/blog/geo-engineering-climate-geobad-idea.

88. Herb Lin, "Large-scale geoengineering and threats to national security," Lawfare, October 31, 2015, https://www.lawfareblog.com/large-scale-geoengineering-andthreats-national-security.

89. Cockburn, “Anthropogenic." 


\section{ABSTRACTS}

The goal of this article is to review the various positions taken by free-market conservative and libertarian public policy experts regarding solar geoengineering. A quantitative analysis and a qualitative analysis of the online publications of ten major free-market think tanks are provided with a view to determining whether free-market conservative and libertarian experts are embracing solar geoengineering as a key solution to climate change. Specifically, the article looks at how prominent solar geoengineering is in the publications of free-market think tanks, gauges their level of support for or hostility toward solar geoengineering, and lists the arguments that they use for or against it. The analysis shows that solar geoengineering is still a marginal topic of discussion in the world of free-market think tanks, but that a majority of the experts who have considered solar geoengineering tend to support funding for research, often as an alternative to mitigation policies.

\section{AUTHOR}

\section{JEAN-DANIEL COLLOMB}

Jean-Daniel Collomb is a professor of American studies at Université Grenoble Alpes. His research is focused on environmental issues in the United States and on the history of the social movements intent on preserving the environment in the United States from the mid-19th century to the present time. He is the author of John Muir, parcs nationaux et écologie (2013) and Une histoire de la radicalité environnementale aux ÉtatsUnis (2018). He has also written several articles about the opposition between the American Right and the US environmental movement from the early 1980s to the present time. 